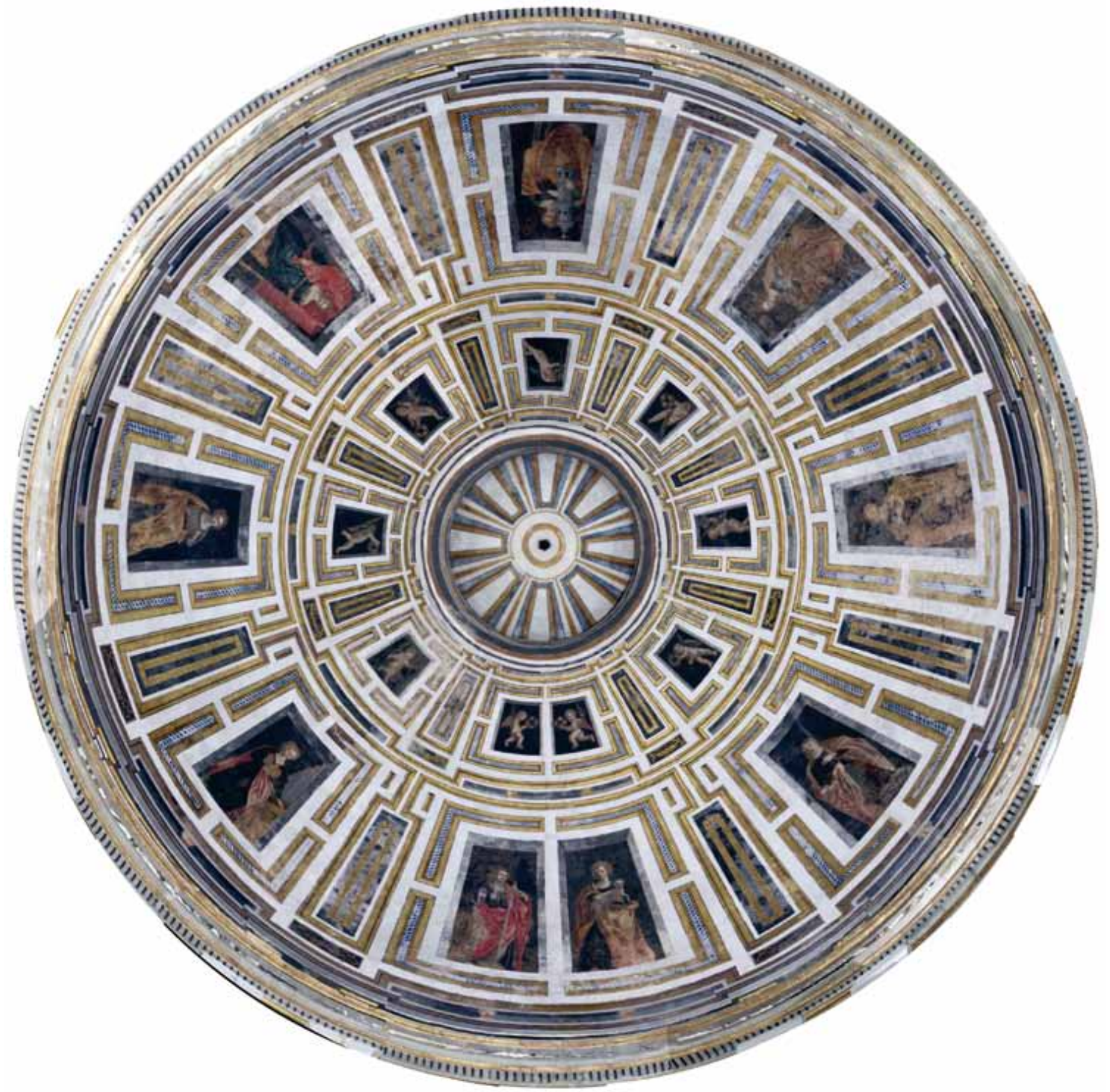




\section{Una mirada propositiva sobre un patrimonio iconográfico por desvelar: la iglesia del Santo Cristo de la Salud de Málaga}

Aurora Villalobos Gómez, M. ${ }^{a}$ del Mar González González, José Luis Gómez Villa, Centro de Intervención del IAPH

\section{Resumen}

Este artículo presenta los contenidos del Proyecto de Intervención en el Programa Iconográfico de la iglesia del Santo Cristo de la Salud de Málaga, cuyo objeto es la conservación integral, puesta en valor y difusión de este bien de interés cultural. Se trata de un inmueble único en la tipología jesuítica que acoge un singular y extenso programa iconográfico sobre el martirologio constituido por pinturas murales, retablos y esculturas ejecutados desde su origen hasta nuestros dias. El proyecto viene motivado por el mal estado de conservación de los bienes y las transformaciones a las que han sido sometidos en intervenciones anteriores.

En este marco se firmó en el año 2009 un convenio de colaboración entre la Consejería de Cultura de la Junta de Andalucía, el Instituto Andaluz del Patrimonio Histórico, la Fundación Caja Madrid y el Obispado de la Diócesis de Málaga, por el que el IAPH está llevando a cabo la gestión de este proyecto de conservación. Esto ha implicado su redacción por parte de un equipo interdisciplinar del Centro de Intervención siguiendo la metodología de estudio e intervención consolidada en los últimos veinte años, desde la premisa fundamental de "conocer para intervenir".

Se espera que el desarrollo de estos trabajos sea una oportunidad única de aumentar el conocimiento sobre dicho bien y de implicar a la sociedad en los procesos de intervención en el patrimonio cultural andaluz.

\section{Palabras clave}

Instituto Andaluz del Patrimonio Histórico / Centro de Intervención / Proyectos de conservación / Intervención en el patrimonio histórico / Patrimonio Inmueble / Iglesia del Santo Cristo de la Salud / Málaga 


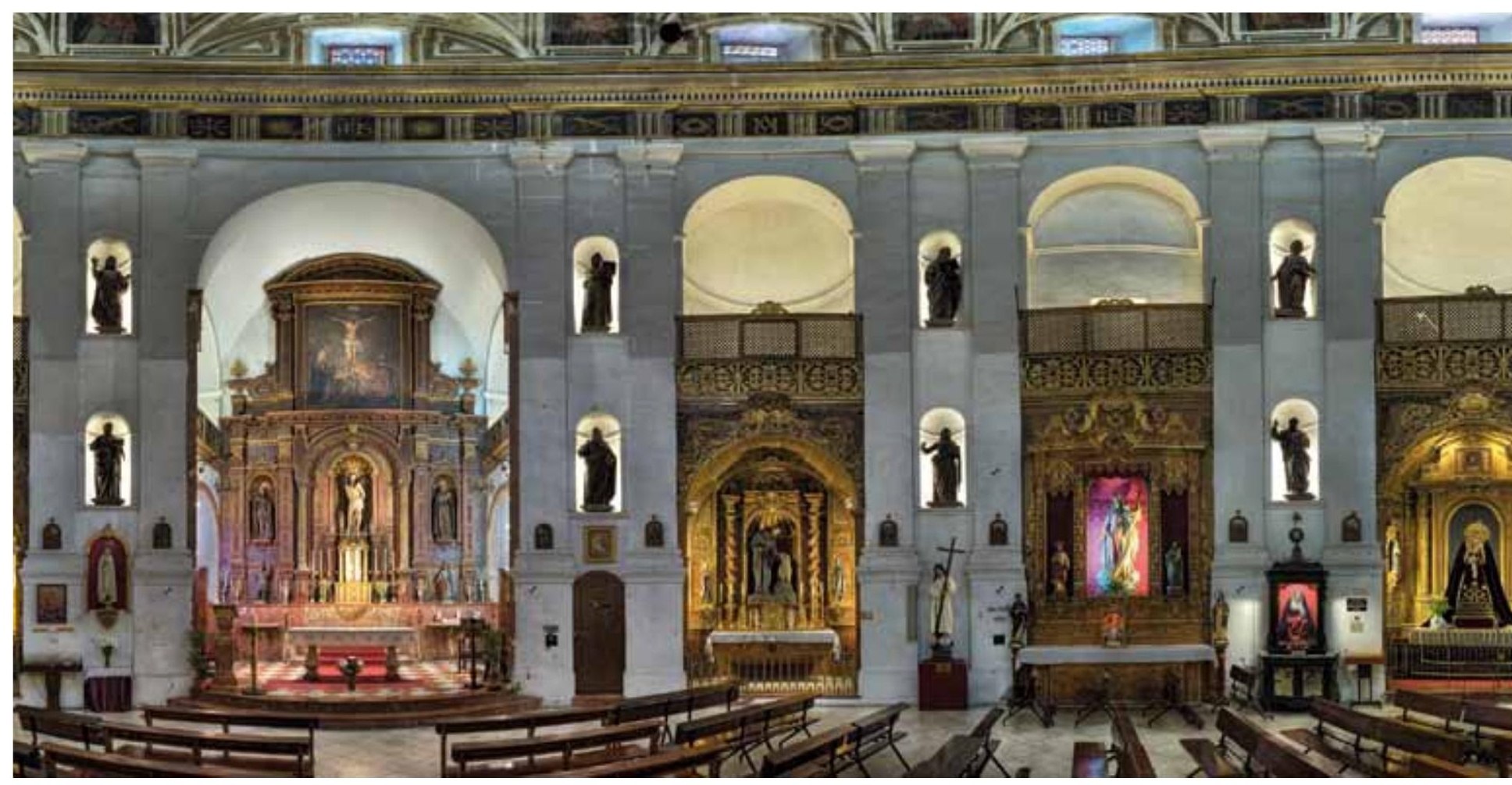

Panorámica del alzado interior. Foto: Fondo Gráfico IAPH Uuan Carlos Cazalla)

\section{EL PUNTO DE PARTIDA}

\section{El monumento como documento construido}

La actual iglesia del Santo Cristo de la Salud, patrón del Cabildo Municipal de la ciudad de Málaga, es uno de los referentes arquitectónicos, culturales y cultuales de mayor importancia y presencia física y espiritual de la ciudad. Asentado en el mismo corazón de ésta, su ingreso por la calle Compañía rememora aquel originario propietario y edificador, la Compañía de Jesús. Y es que la iglesia dedicada originariamente al mártir San Sebastián fue el templo de un potente colegio para la formación de los hermanos de la Compañia, que se asentó con carta fundacional en 1572 en la ciudad de Málaga, coincidiendo con la primera gran expansión de la orden de los soldados de Cristo, tan sólo treinta y dos años después de su constitución oficial ante el pontífice Pablo III.

La extensa historia de la edificación final del colegio y, en especial, del templo, no es el objetivo de la presentación de este proyecto, aunque algunos aspectos de esa historia son valores indisolubles que lo han propiciado. A pesar de las férreas directrices edificatorias de la orden, el colegio de los Jesuitas de Málaga se convierte en uno de los escasos ejemplos de arquitectura de planta centrada jesuítica, no sólo de España sino del mundo, saliéndose de la norma trazada por el Gesú de Roma, máxime en el momento de su temprana planificación, al final del XVI. Literalmente inspirado en uno de los dibujos del Libro IV de Serlio, el templo malagueño ejemplifica ese tipo de arquitectura de estilo clásico tardo renacentista que se ha difundido como de orden manierista. Un círculo inserto en un espacio cuadrado, en el que se trazan capillas embutidas en los muros en los ejes secundarios, dejándose los principales como líneas de cruce entre los espacios del convento y su relación con la calle, excepto el remarcado en profundidad del presbiterio.

Un alzado de orden apilastrado gigante y cubierto por una bóveda semiesférica con cupulin remarca la idea martirial del templo, que unifica la primitiva advocación de San Sebastián al espíritu jesuita del sacrificio, haciendo partir ese concepto iconográfico desde la arquitectura a su ornamentación. Iniciada ésta inmediatamente tras la edificación, las pinturas murales de la bóveda consolidan ejemplarmente esa idea de los primitivos mártires y santos al servicio de la cristiandad, constituyendo en sí un ejemplo único de pintura mural manierista, en la que la arquitectura fingida prolonga las líneas edificadas para albergar una serie de casetones y de efectos lumínicos o de color, en los que se insertan las representaciones hagiográficas. Este discurso iconográfico se prolongó después a la ornamentación de las capillas de los ejes secundarios, primero en pintura mural (ahora parcialmente velada) y después con retablos que albergasen las principales causas de santidad de la orden, originariamente dedicados a San Francisco de Borja, Santos Mártires del Japón y San Ignacio de Loyola, más el retablo mayor dedicado a San Sebastián.

Unifica además el templo del Santo Cristo de la Salud una serie de valores que lo llevan a nuestro tiempo, valores vinculados a sus cambios de uso que han garantizado su persistencia patrimonial. A pesar de la direccionalidad exhaustiva de la construcción jesuita, la expulsión de la Orden en 1759 va a conllevar una serie de cambio de usos y de algunos de los elementos de su ornamentación condicionados por éstos. Entre los primeros destaca esa prioridad por adecuar siempre sus dependencias a la docencia, que hacen 


\section{EL PROYECTO DE CONSERVACIÓN COMO HERRAMIENTA DE CONOCIMIENTO}

\section{La dificultad de definición del ámbito de actuación}

Esta decisión estratégica no condiciona de manera directa la definición del ámbito de actuación, ya que se trata conceptualmente de una única actuación patrimonial que, para conservar este singular programa iconográfico, requiere previamente frenar en el inmueble las causas de deterioro que afectan a la integridad de los bienes muebles. Precisamente porque todo está relacionado es difícil definir el ámbito de actuación sin considerar la diversa naturaleza de los bienes muebles e inmueble presentes.

En los bienes muebles no basta con identificar las pinturas murales de la cúpula, los retablos y las esculturas ubicadas en las hornacinas de los paramentos del templo, sino que hay que considerar la presencia de otros elementos debidos al uso del edificio. En primer lugar, se reconocen numerosos bienes de carácter cultural (imágenes devocionales, vitrinas) y cultual (tales como mobiliario, señalética e instalaciones) que ha sido preciso inventariar para poder tener un criterio acerca de los que están vinculados al programa iconográfico y los que son prescindibles o incluso han quedado obsoletos. En segundo lugar, ante la posibilidad de recuperar unas pinturas murales ocultas en los paramentos por sucesivas intervenciones de encalado, se ha llevado a cabo un programa de catas -refrendado por la documentación analizada desde el prisma histórico- que ha permitido no sólo determinar la viabilidad de su recuperación sino conocer mejor las distintas etapas constructivas del edificio y sus transformaciones. En con- creto, se ha constatado la presencia de decoración mural oculta en los pedestales de los paramentos (a modo de falso marmoleado), y en los capiteles de las pilastras (simulando triglifos, filete y gotas) asi como en los frentes de los balcones (simulando una balaustrada bajo la rocalla). Parece que, tanto la capilla donde actualmente se halla la Cofradía de Estudiantes como la que se dispone enfrente de ésta se decoraron de modo similar a la cúpula, según testimonios escritos.

De igual modo, en el inmueble tampoco se ha estimado suficiente intervenir estrictamente en la cúpula que sirve de soporte a las pinturas murales o los paramentos donde se apoyan los retablos y se disponen las esculturas, sino que ha sido necesario un proceso de discernimiento donde, a las actuaciones derivadas de las necesidades de conservación (en cúpula, cubierta, torre y paramentos interiores), se han incorporado otras: concernientes al entendimiento de la unidad tipológica y constructiva del edificio en su contexto, con independencia del régimen de usuarios (es asi que se propone actuar sobre la fachada completa del antiguo colegio-noviciado y no sólo sobre el tramo de alzado de la iglesia); las relacionadas con la oportunidad de mejora de prestaciones a los usuarios (especialmente a nivel de pavimentos para resolver la accesibilidad dentro y fuera del edificio, y de mobiliario para liberar superficie útil en los recorridos por la nave y permitir nuevas posibilidades de uso litúrgico en el presbiterio); y en apoyo de la puesta en valor del programa iconográfico (incorporando un proyecto de iluminación monumental en el interior para percibir los colores desvelados por la restauración y dotar al espacio de coherencia arquitectónica, reconociendo elementos y espacios preexistentes que habian sido transformados sin criterio alguno).

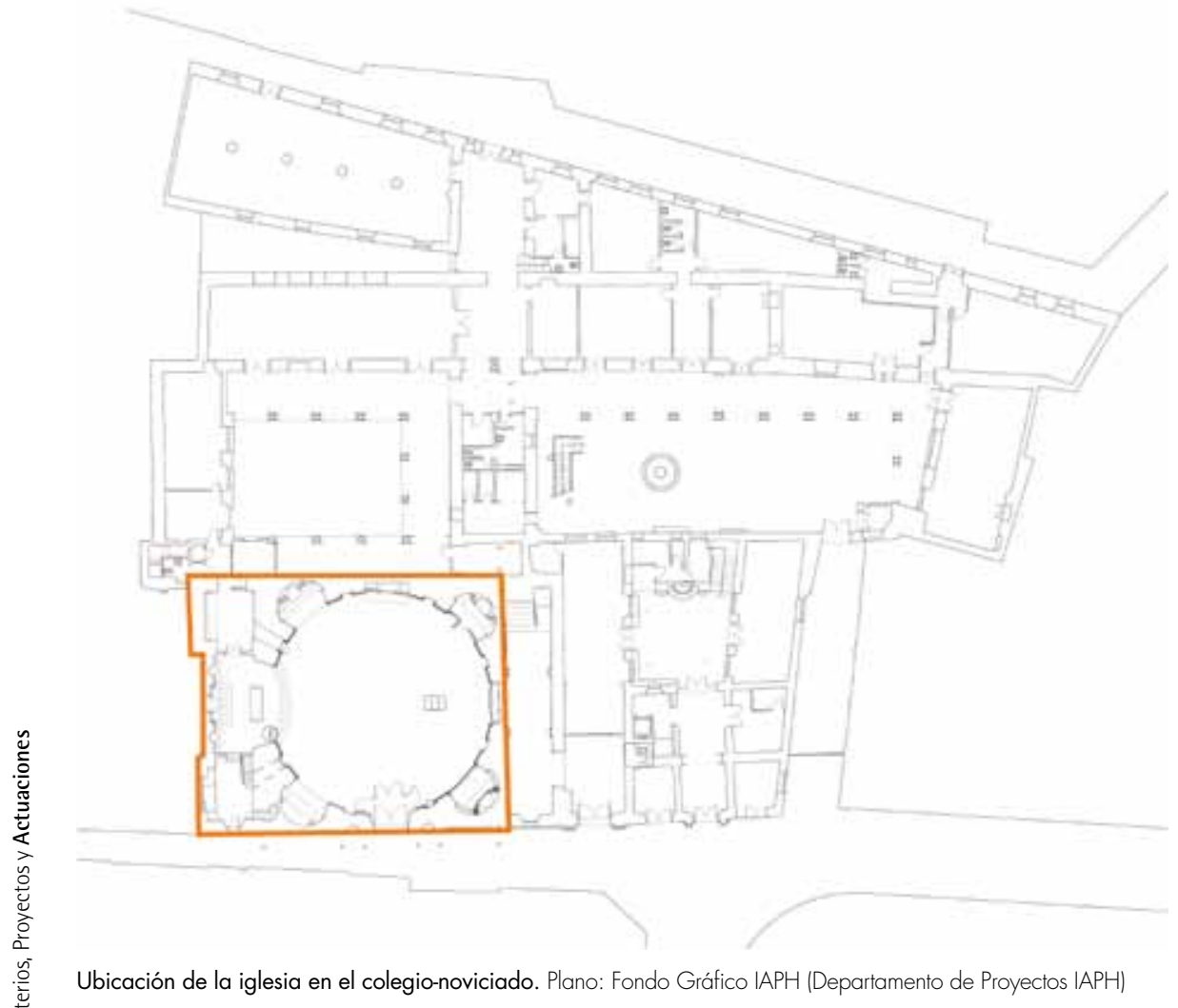

1-2, 5-8, 9-10, 12-16. Fotos: Fondo Gráfico IAPH (José Manuel Santos Madrid) 3-4. Fotos: Fondo Gráfico IAPH (Aurora Villalobos Gómez)

11. Foto: Fondo Gráfico IAPH (Fernando Guerra-Librero) 

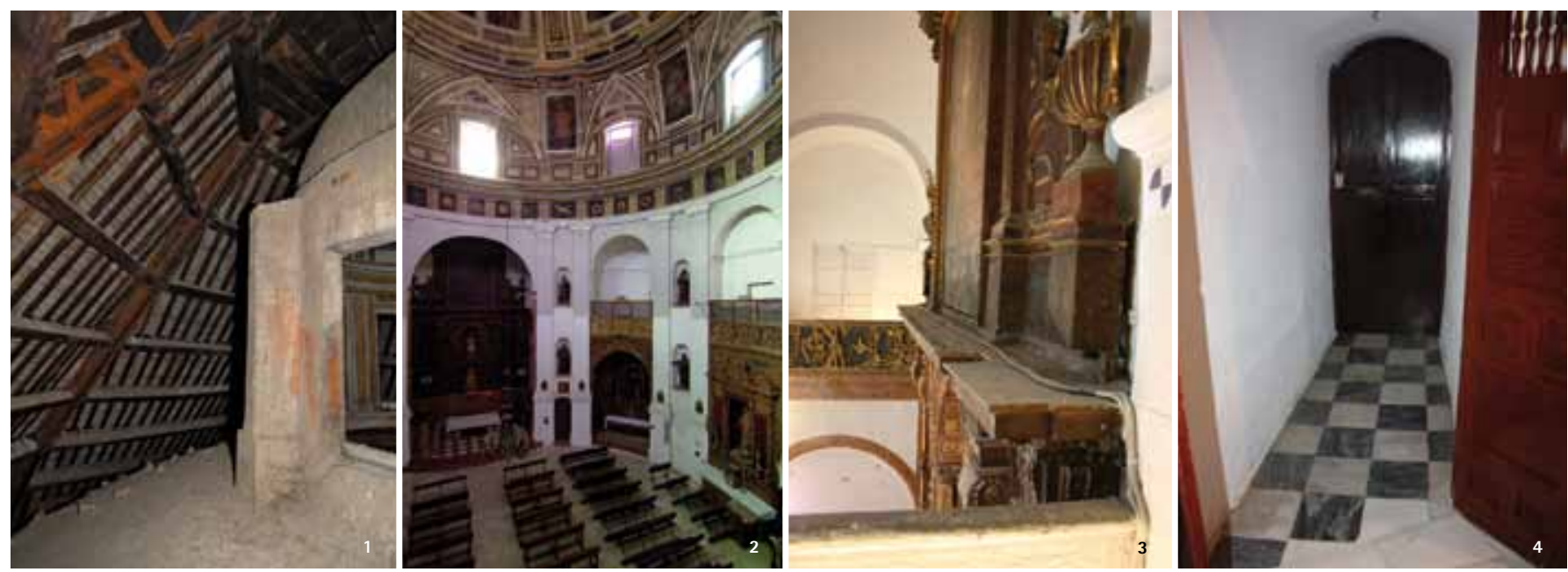

Identificación de espacios culturales
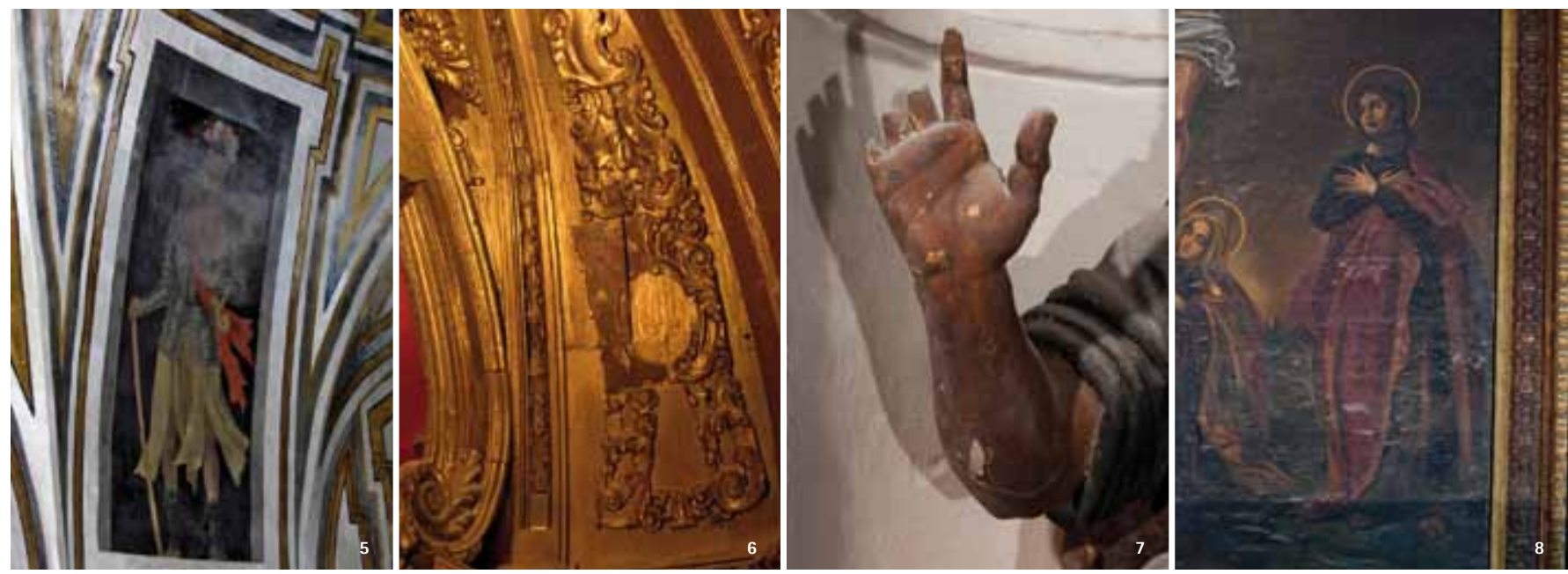

Estado de conservación de los bienes muebles
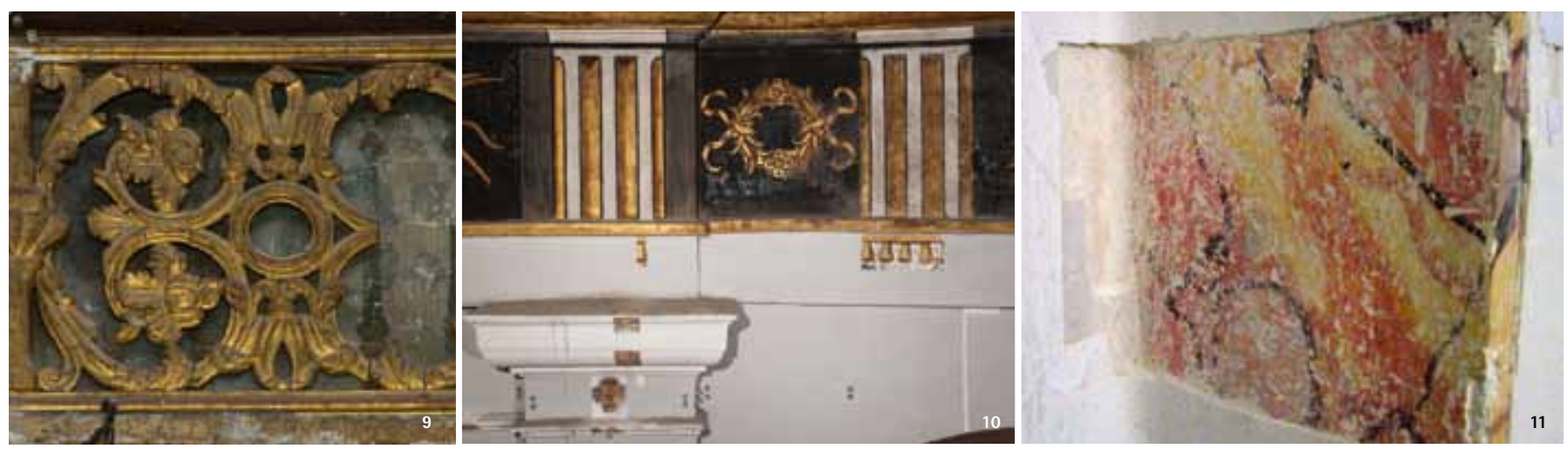

Programa de catas de pintura mural
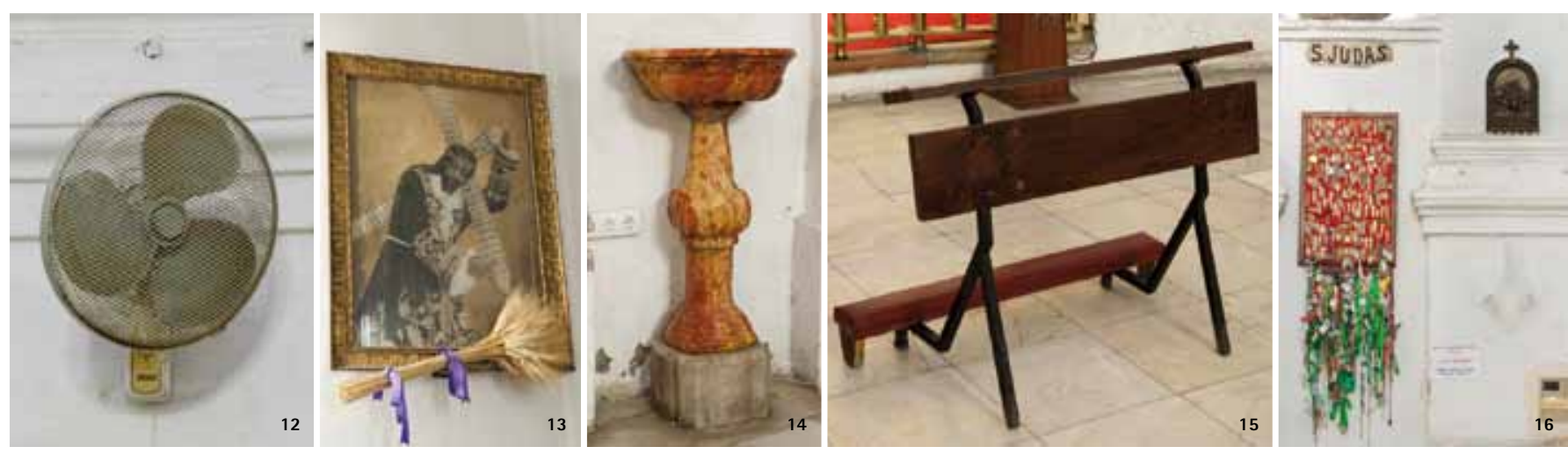

Inventario de bienes muebles culturales y cultuales 


\section{Desde la metodología de estudio hacia los criterios de intervención}

Es sabido que el IAPH cuenta con una metodología de estudio e intervención muy consolidada basada en el principio de "conocer para intervenir". En contextos patrimoniales tan modificados y vulnerables, éste es el sentido de trabajar en equipos interdisciplinares donde los distintos estudios previos aportan conocimientos especializados que ayudan a delimitar el ámbito de actuación, priorizar los objetivos de la propuesta y definir los criterios de intervención. Ciertamente, por cuestiones de eficacia y economía de recursos, dichos estudios deben acordar cada vez mejor sus tiempos con los de redacción del proyecto, permitiendo la transferencia de información casi en paralelo ya que, lejos de considerar el proyecto como un hecho consumado una vez redactado, somos conscientes de la condición viva de todo proceso. $Y$ es que en este caso, también la intervención va a permitir conocer mejor los bienes culturales ("intervenir para conocer") por medio de un proceso de des-restauración: desvelando lo que está aparentemente visible y descubriendo algunos elementos que habian quedado ocultos.

No queremos insistir en cuestiones que ya han sido ampliamente tratadas en diversos foros, sino más bien apuntar las novedades metodológicas que se asumen en esta propuesta. Sea, por ejemplo, la incorporación del "libro del edificio" como documento técnico en los proyectos patrimoniales; procedente del ámbito de obra nueva y concebido para reunir toda la documentación de la obra ejecutada y definir el programa de conservación y mantenimiento del edificio, pensamos que garantiza mejor los resultados de la intervención directa de conservación dando pautas de mantenimiento a los propietarios. De especial incidencia en el proyecto sobre el inmueble son el Código Técnico de la Edificación (CTE que establece los requisitos básicos que deben satisfacer los edificios con el fin de garantizar la seguridad de las personas, el bienestar de la sociedad y la protección del medio ambiente) y el Decreto 293/2009 por el que se aprueba el Reglamento que regula las normas para la accesibilidad en las infraestructuras, el urbanismo, la edificación y el transporte en Andalucia (que desarrolla de forma más exhaustiva las cuestiones de accesibilidad). Si bien podemos acogernos a la exención de su cumplimiento estricto por la posible incompatibilidad de las medidas exigidas con el grado de protección de los edificios (CTE, art. 2) y la existencia de condicionantes de tipo histórico y artístico (Decreto 293/2009, disposición adicional primera), se ha considerado interesante incorporar -a modo de medidas complementarias y como parte de un buen diseño- aquellas cuestiones de accesibilidad universal y seguridad en caso de incendio que pudieran mejorar las prestaciones actuales del edificio sin menoscabo de sus valores culturales, precisamente porque el patrimonio es una construcción cultural en la que los destinatarios también tienen que ser protagonistas.

En relación con lo anterior, otro aspecto a destacar es que, dado que la tutela de los bienes culturales actualmente no se compren- de sólo desde la óptica de la conservación o la documentación, el proyecto se acompaña en todo momento de un plan de difusión del que este artículo es una iniciativa. En un bien tan vivido como éste con un alto significado de pertenencia, entendemos que es fundamental implicar a la sociedad en los procesos, la mayoría de las veces muy prolongados en el tiempo y con afecciones que deben compensarse con otras medidas que garanticen la comprensión de las soluciones adoptadas y el uso y disfrute de los bienes tras la intervención. No podemos olvidar que toda intervención se realiza desde el presente, aportando una componente contemporánea que es inevitable en la medida en que no sólo conservamos el bien (intervenimos sobre el objeto) sino que actualizamos sus valores culturales (para el sujeto que lo reconoce como tal).

A partir de aquí podemos analizar cómo el proyecto comienza a responder a los criterios generales de intervención en patrimonio cultural consensuados en numerosas cartas internacionales y los emanados de la legislación vigente:

- Actuación justificada por la conservación. En este sentido, la actuación no responde a una motivación de carácter estético ya que la intervención no es un fin en sí mismo sino un medio al servicio del bien cultural en su conjunto. Se ha decidido detectar y eliminar previamente a la intervención los factores de deterioro que directa (humedades de infiltración) e indirectamente (ventilación) han incidido en el estado de conservación de las pinturas murales de la cúpula (el bien mueble más afectado), potenciando la aparición de alteraciones en él.

- Mínima intervención. Desde la concepción del edificio como documento vanguardista de su tiempo -con un singular y extenso programa iconográfico materializado en un conjunto de pinturas murales y bienes muebles asociados-, consideramos que nuestra propuesta sigue este criterio ya que no se modifica el estado de cargas, el equilibrio higrotérmico o las densidades de uso, garantizando la consistencia física del elemento. La espacialidad interior si se recupera en tanto que actualmente es incomprensible debido a sucesivas modificaciones de uso que han alterado la conformación y apreciación del conjunto, cambios que conllevaron asimismo nuevas advocaciones en el programa iconográfico original de las capillas, en correspondencia directa con la traza centralizada del edificio y la presencia de numerosos elementos de culto. Igualmente, instalaciones obsoletas y sin valor cultural contaminan la percepción del espacio.

- Respetar la autenticidad de la obra. La intervención respeta la condición histórica (evolutiva), estética y arquitectónica del bien, presentándolo como un testimonio del pasado sin modificar el entendimiento de su cronología, materia original o contexto tipológico-espacial. Desde este punto de vista, ante la posibilidad de pinturas murales ocultas en los paramentos interiores de la nave, se toma la decisión de recuperarlas si es viable desde el punto de vista técnico ya que contribuirán a un mejor entendimiento del espacio, dotando de proporción a los órdenes arquitectónicos con 
una línea de pedestal, potenciando la simetría de las diagonales en planta y marcando las áreas de culto en correspondencia con los umbrales del mismo color. Como hemos apuntado anteriormente, la conservación de los bienes adquiere el carácter de una des-restauración de los mismos.

- Discernibilidad. La intervención intenta ser fácilmente reconocible para que no constituya un falso histórico, estético o arquitectónico que afecte a la imagen del elemento o sus condiciones de estabilidad. Esto no significa que tenga que ser necesariamente muy contrastada, ya que podría producirse el efecto contraproducente de entender de manera independiente la nueva actuación respecto a la preexistencia.

Desde este punto de vista, las reintegraciones (volumétricas y superficiales) son una cuestión de primer interés en este proyecto. Se tratan de diversa manera según afecten al estado de conservación de los bienes o la percepción del conjunto para que la laguna no destaque, quedando siempre constancia visible en un segundo plano del acto de reintegración. Es por eso que, en el caso de ser necesarias, se harán con los materiales originales para garantizar también la compatibilidad con el soporte: es decir, piedra, ladrillo y mortero de cal al exterior, y revestimiento de yeso y pintura al temple al interior; aquéllas realizadas con piezas de madera podrán quedar vistas, entonadas con la circundante mediante veladuras de acuarela o resina acrílica pigmentada, de forma que su impacto visual quede minimizado. En el caso de las pinturas murales, las reintegraciones superficiales o adiciones serán las imprescindibles para minimizar la presencia de las lagunas, garantizando la conservación de las policromías originales en el futuro y la lectura visual de la obra. Se espera encontrar estrato polícromo en la cúpula bajo algunos depósitos superficiales que actualmente ofrecen una apariencia de pérdida.

- Reversibilidad. Entendida en el caso de los bienes muebles en el sentido de que los tratamientos y productos aplicados puedan eliminarse con el fin de facilitar intervenciones futuras. En el caso de los bienes inmuebles es más difícil plantearlo en estos términos ya que los sistemas constructivos tienden a ser permanentes; más bien se proponen las actuaciones pensando que pueden mejorarse sin afectar a las características intrínsecas del bien. De nuevo la discernibilidad y la documentación de las obras serán la base de la futura reversibilidad.

- Compatibilidad. Los materiales y tratamientos empleados deben ser compatibles entre sí y con el bien, debiendo ofrecer resultados suficientemente contrastados por la experiencia. Se parte de la constatación de que algunas intervenciones han podido ser contraproducentes. Es por eso que, como actuaciones previas se eliminan aquellos materiales que se sabe que son perjudiciales para el bien (cemento en recercados, yesos en revestimientos exteriores) y a lo largo de la ejecución se propone realizar ensayos para garantizar la eficacia, durabilidad y compatibilidad de los materiales de conservación propuestos (consolidantes, hidrofugantes, desalinizadores, protectores de la oxidación, biocidas, herbicidas, morteros de llagas y morteros de revestimiento).

- Documentación detallada de la intervención. Al final de los trabajos se entregará una memoria final de la intervención donde quedará recogido todo el proceso de obras así como el libro del edificio para facilitar y garantizar la discernibilidad y reversibilidad respecto al bien antes, durante y después de la intervención.

Los criterios específicos atienden a la tipología del bien a tratar y sobre todo a las necesidades de actuación, en función de los resultados aportados por los estudios previos.

\section{APORTACIONES DEL PROYECTO}

\section{Cómo se construye la nueva mirada}

Entendemos que, en definitiva, el proyecto propone conservar unos valores culturales que trascienden la materialidad de un objeto complejo, formado por un conjunto de bienes muebles e inmueble. Como se ha producido una contaminación visual en el interior debido a la superposición de elementos cultuales, no es explícito el programa iconográfico (las capillas se confunden con los altares laterales), no se percibe la nave como un espacio continuo centralizado (el paramento con tres tonos de blanco y la iluminación fluorescente en la cornisa interrumpen la secuencia del paramento con la cúpula; asimismo la lámpara de araña no permite contemplar las pinturas murales de la cúpula) y las tribunas han quedado como espacios residuales (como consecuencia del régimen de usos compartimentado del antiguo colegio-noviciado). Por lo tanto, no se trata sólo de procurar la conservación del conjunto desde la escala del edificio a la de detalle de los bienes muebles, sino de recuperar la componente perceptiva y simbólica de un espacio actualmente distorsionado, precisamente por su intensidad de uso y algunas intervenciones sin criterio llevadas a cabo en las últimas décadas.

Las actuaciones propuestas en el siglo XXI deben venir determinadas por un balance entre el valor cultural del bien, su estado de conservación y las condiciones de uso y disfrute de los usuarios, que son quienes lo reconocen como patrimonio y se identifican en él. Es por ello que se reconocen tres líneas de decisiones:

\section{Respecto a la conservación del edificio y sus bienes muebles asociados}

Nuestro interés se centra en frenar el deterioro en las pinturas murales que son el elemento del programa iconográfico que se ha visto más afectado. Su estado de conservación es el resultado no sólo de la intervención de los diversos agentes de deterioro que normalmente actúan en un edificio, sino también de su propio diseño.

El sistema constructivo constituido por cúpula, cámara y cubierta es el que tiene mayor incidencia en la conservación de las pinturas 
El proyecto de conservación se desarrolla en los siguientes documentos técnicos de naturaleza investigadora y propositiva.

\section{0 . Documento de bases y estrategia}

1. Levantamiento planimétrico

2. Estudios de técnicas de examen por imagen

3. Estudios analíticos

4. Estudios medioambientales

5. Estudio histórico

6. Proyecto de conservación de bienes muebles

7. Proyecto básico y de ejecución de intervención en el inmueble

8. Proyecto de andamios, instalaciones y medios auxiliares

9. Estudio de seguridad y salud

\section{DOCUMENTO DE BASES Y ESTRATEGIA:}

Es el documento técnico que articula los contenidos de los distintos documentos especificos que constituyen el proyecto de conservación, actualizándose en cada fase del proceso. De este modo, previamente a la intervención, recoge las líneas generales de la propuesta planificada de manera conjunta para los bienes muebles e inmuebles. Durante el proceso de obras, tendrá el carácter de informe común del estado de los trabajos en coherencia con las estrategias planteadas. $Y$ con la finalización de los trabajos asumirá el carácter de memoria final de la intervención donde quedarán recogidas todas las actuaciones ejecutadas.

1. LEVANTAMIENTO PLANIMÉTRICO: memoria, planos / soporte digital Planimetría 2D

Modelado 3D

Entendido el levantamiento planimétrico como la herramienta de conocimiento fundamental para la aproximación a la realidad física del objeto de intervención, aporta una documentación gráfica válida para el conocimiento del estado actual de conservación del bien y comprensión de su vida material. Se desarrolla a dos escalas de representación: la del antiguo colegio-noviciado, actualizando una planimetria base del año 1987 facilitada en papel por el arquitecto Salvador Moreno Peralta a escala 1:100; y la de la iglesia, a partir de un exhaustivo escaneado láser del objeto que ofrece una planimetria y ortofotografías hasta la escala 1:20, con una precisión superior a $2 \mathrm{~mm}$. Además, siendo soporte gráfico de la propuesta actual, queda como documento de las actuaciones previstas disponible para futuras intervenciones.

\section{ESTUDIOS DE TÉCNICAS DE EXAMEN POR IMAGEN:}

\section{informe técnico / soporte digital}

Fotografia con luz visible de los bienes muebles y del inmueble

Fluorescencia ultravioleta en bienes muebles

Termografía en el inmueble

Se presenta como una herramienta de conocimiento fundamental tanto para la aproximación a la realidad física del objeto de intervención (estado de conservación actual, identificación de elementos culturales y cultuales, tales como mobiliario, señalética e instalaciones) como para la documentación de las labores desarrolladas durante el proceso de intervención (por ahora el seguimiento del programa de catas de pintura mural), la evolución de los tratamientos y el estado final tras la actuación. Ofrece un material muy interesante para la difusión a base de imágenes panorámicas a $360^{\circ}$ dinámicas en alta resolución.

\section{ESTUDIOS ANALITICOS}

informe técnico

Caracterización de materiales

Identificación de factores de alteración Evaluación de nuevos materiales y productos de tratamiento

El estudio de la materialidad del bien nos permite conocer su comportamiento y cronología para constatar intervenciones anteriores, identificar los agentes de deterioro y evaluar los productos de intervención. Se acomete desde las especialidades de la geología, la quimica y la biología. Las pinturas murales conllevan la mayor parte de los estudios, contemplando la comparación entre las existentes en la cúpula y las que aparecen en los paramentos. También requiere gran interés el comportamiento de los revestimientos de yeso en la galeria de cubierta, por donde se han venido produciendo las mayores filtraciones de humedad.

\section{ESTUDIOS MEDIOAMBIENTALES: informe técnico}

Estudio climático

Estudio de la contaminación atmosférica

Estudio de la luz

Estudio termo-hidrográfico

Este estudio resulta fundamental para conocer las condiciones de equilibrio del interior y la incidencia de los factores medioambientales desde el exterior antes de la intervención y para evaluar el comportamiento del edificio tras la intervención, debido a la recogida sistemática de datos a lo largo de todo el proceso de intervención. La conser- vación preventiva nos aporta criterios para el mantenimiento del edificio, los bienes muebles y las instalaciones.

\section{ESTUDIO HISTÓRICO:} informe técnico

Linea A: aplicada al proyecto de intervención

Linea B: aplicada al conocimiento total del conjunto patrimonial y a la reflexión que ello genere.

El objetivo fundamental del estudio histórico es esclarecer la historia material y transformaciones del inmueble $y$ de los bienes muebles, posibilitando la interpretación de los criterios y la toma de decisiones de carácter conservativo y de puesta en valor. Se ha dividido a efectos funcionales en dos apartados; de un lado la evolución histórica de inmueble, con especial atención a la edificación de los jesuitas, a sus cambios de usos y a las transformaciones y modificaciones hasta nuestros dias; por otro, y aislado en capitulos independientes, se han tratado las pinturas murales y su especial peso en la simbologia del programa iconográfico, asi como su vinculación directa entre el estado de conservación y el del inmueble; las esculturas de bulto redondo del apostolado de las hornacinas entre pilastras; los retablos de las capillas de los ejes secundarios del templo, que no fueron sustituidos sino transformados para conferirles un aspecto barroco tardío dotándolos de nuevas devociones que sustituyeron las originales jesuiticas; los retablos añadidos en el s. $X X$ y el resto de elementos muebles que hoy tienen cabida en el templo.

\section{PROYECTO DE CONSERVACIÓN DE BIENES MUEBLES:} memoria, planos, pliego, mediciones y presupuesto Pintura mural I (restauración $571 \mathrm{~m}^{2}$ cúpula) II (descubrimiento en paramentos) Retablos (7)

Esculturas asociadas a paramentos (16)

Este proyecto tiene un marcado carácte conservativo y se propone actuar sobre los elementos muebles que constituyen el singular programa iconográfico de la iglesia, a la vista de que las intervenciones anteriores no han resuelto las patologías existentes.

Partiendo del conocimiento profundo, tanto de la obra como de su entorno, se detallan los procesos y los distintos aspectos que condicionan la intervención y su eficacia. El término "bienes muebles" define y hace referencia al conjunto de elementos que, tras ser analizados y estudiados, se consideran la ornamentación del ámbito de actuación.

\section{PROYECTO BÁSICO Y DE EJECUCIÓN DE INTERVENCIÓN EN EL INMUEBLE: \\ memoria, planos, pliego, mediciones y presupuesto / libro del edificio}

Este proyecto se presenta como complemento de la intervención en los bienes muebles, sabido que es preciso intervenir sobre las causas de deterioro para que la intervención sea duradera a partir del conocimiento exhaustivo de la materialidad del bien (datos técnicos y estado de conservación). Sin embargo, también se proponen otras cuestiones en materia de adecuación funcional y musealización del espacio, con objeto de actualizar las prestaciones del edificio y mejorar la puesta en valor de los bienes culturales, para lo que se realiza un reconocimiento espacial y tipológico del edificio. Es por ello que su ámbito de actuación es más amplio de lo previsto y contempla la intervención en la cripta, tribunas, torre y vía pública además de los espacios cultuales. Hace un esfuerzo por acordar la legislación patrimonial con la de obligado cumplimiento en edificación. Al final de la ejecución de las obras, se propone la redacción de un libro del edificio a modo de manual de su uso y mantenimiento para el usuario, que le informe de las prescripciones, prohibiciones y recomendaciones.

\section{PROYECTO DE ANDAMIOS, INSTALACIONES Y MEDIOS AUXILIARES:}

memoria, planos, pliego, mediciones y presupuesto

Se proyectan tres sistemas de andamios al servicio de las actuaciones de intervención en el inmueble y los bienes muebles: uno exterior en fachada, uno interior perimetral para los paramentos de la nave y otro interior centralizado para la cúpula. Existen otros medios auxiliares para la intervención puntual en el retablo del presbiterio y de las capillas laterales.

\section{ESTUDIO DE SEGURIDAD Y SALUD: memoria, planos, pliego, mediciones y presupuesto}

Es el documento que establece las condiciones de seguridad y salud para la ejecución simultánea de los proyectos de intervención en los bienes muebles, inmueble y de andamios. 
ESTADO ACTUAL

A 1: Presbiterio. Retablo del Santo Cristo de la Salud A2: Capilla de San Francisco de Asís

A3: Altar de Nuestra Señora del Rosario

A4: Capilla de Nuestra Señora de la Esclavitud Dolorosa

A5: Altar del Misterio de las Ánimas

A6: Capilla de Nuestra Señora de Araceli

A7: Capilla de la Hermandad de los Estudiantes

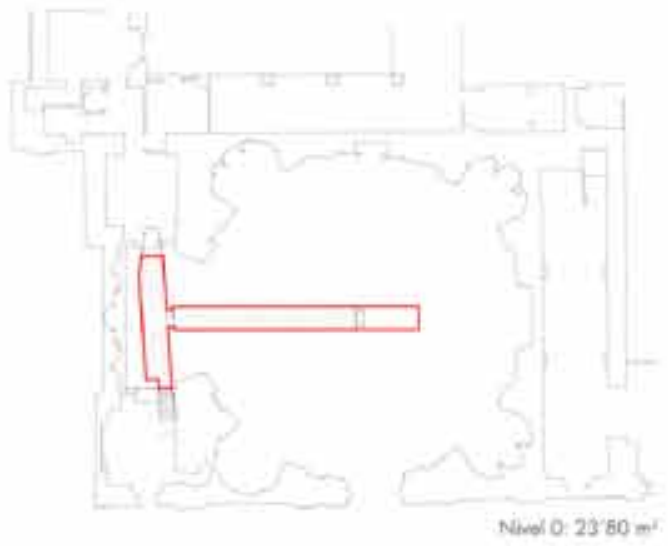

PROPUESTA

Espacio cultual:

Presbiterio

Nave

Capillas

Tribunas

Sacristía

Vestíbulo

Programa iconográfico:

Pinturas murales

Retablos

Esculturas apostolado

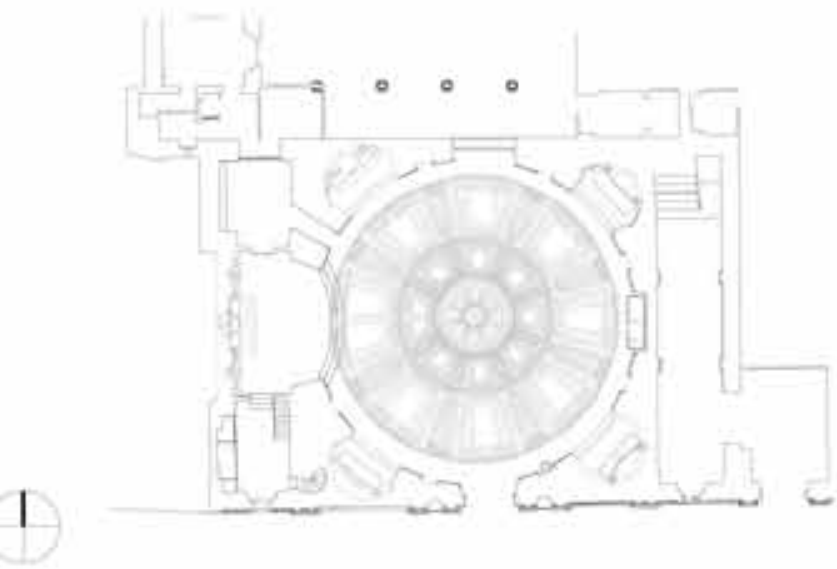

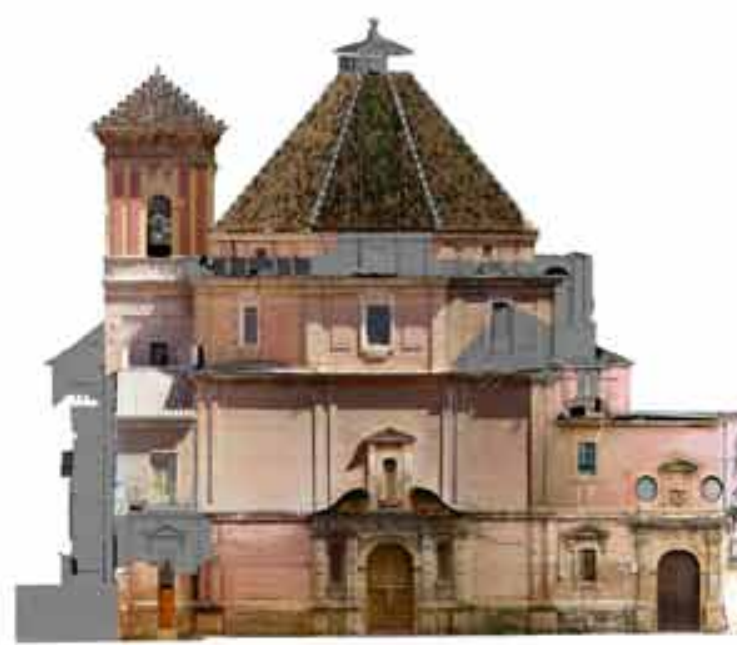
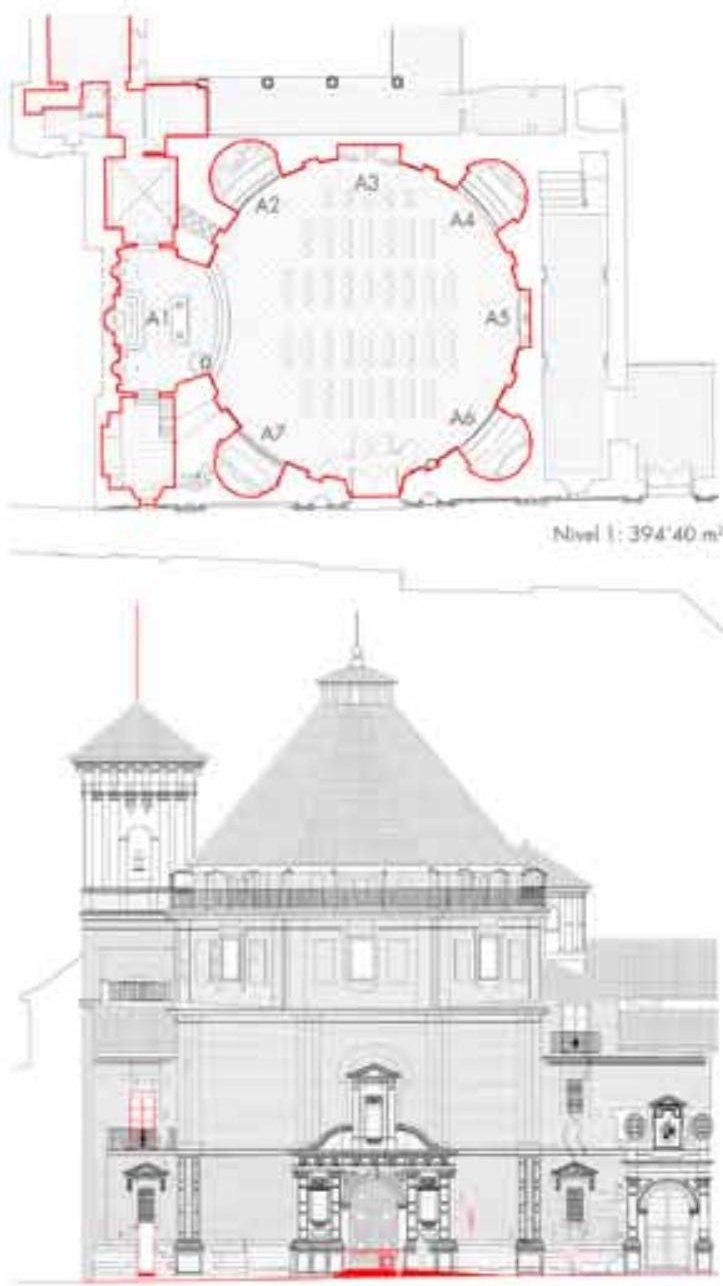

Aloado sur

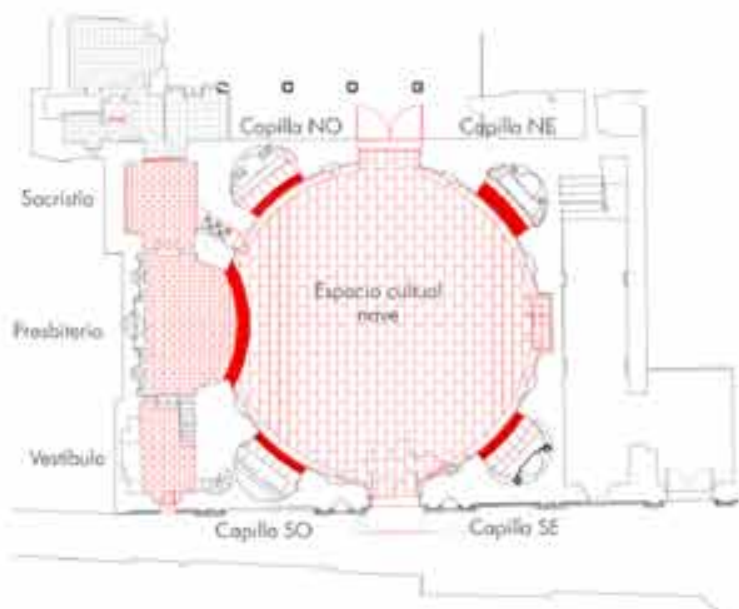



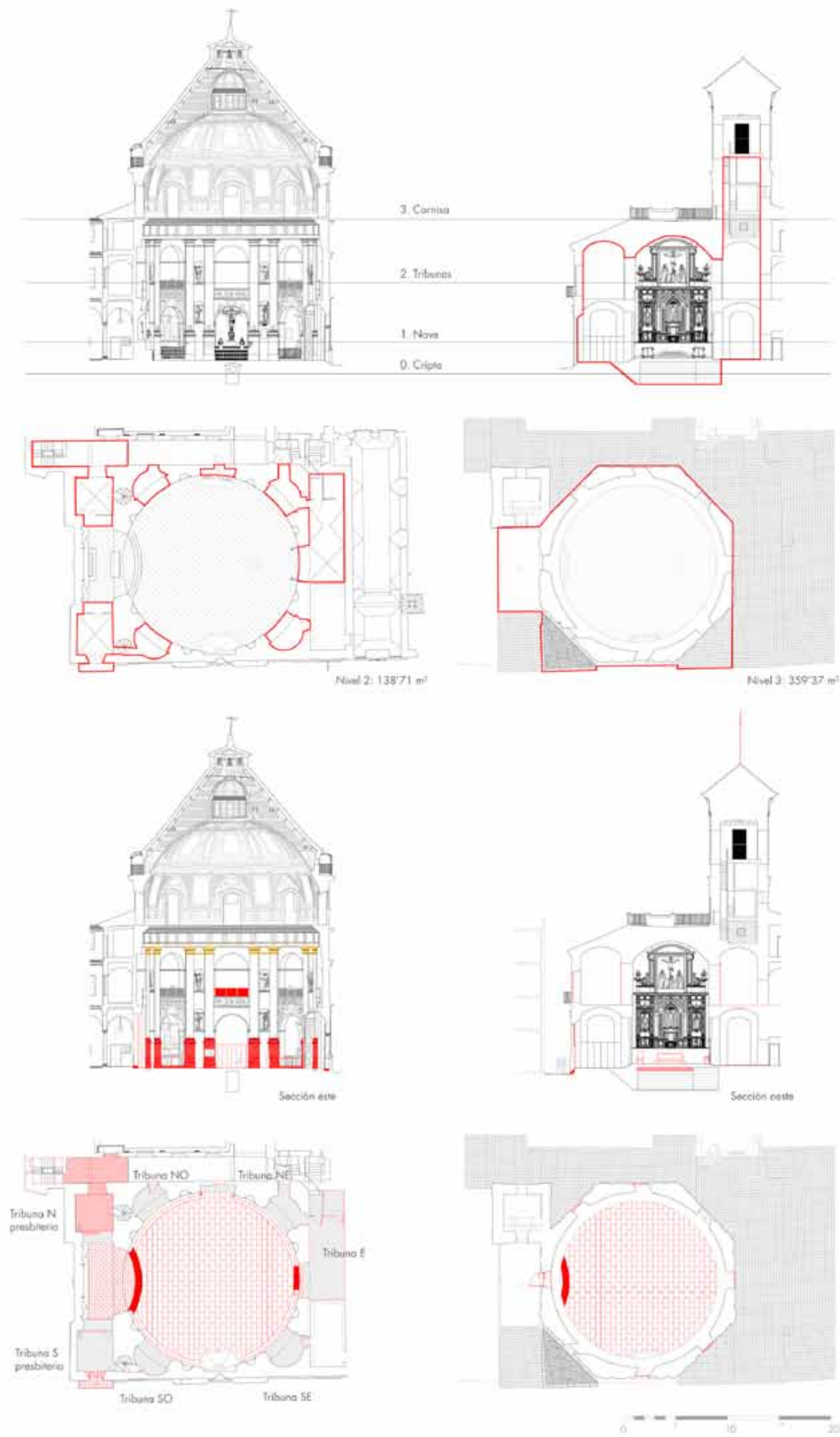

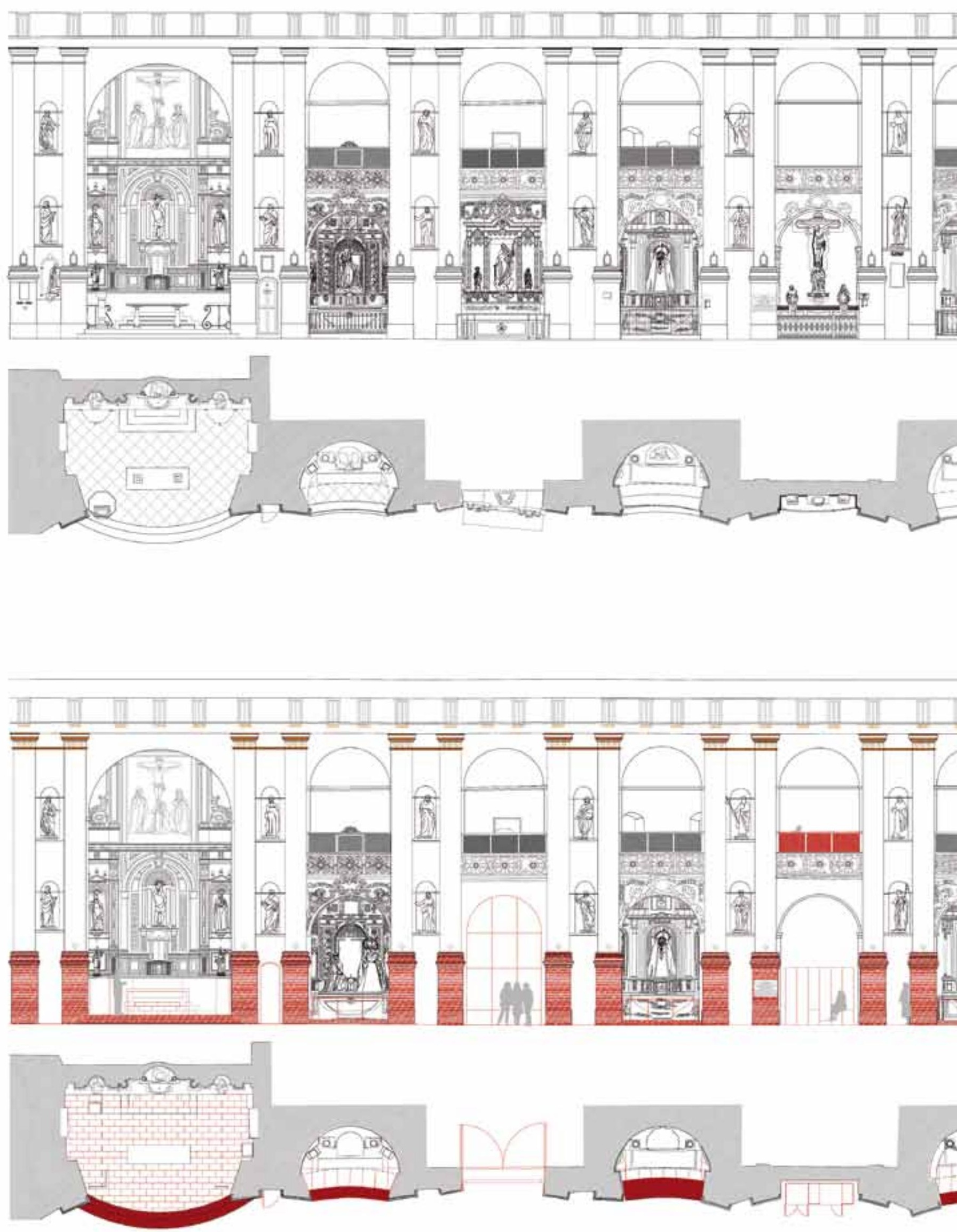
murales, como de hecho delatan las constantes intervenciones en este punto a lo largo de la historia material del edificio. Se piensa que su conformación actual (excesiva pendiente de los faldones de cubierta y ausencia de luz natural a través de la linterna interior de la cúpula) pueda deberse a una modificación de finales del s. XVII. Dado que el estudio medioambiental apunta a que las condiciones de humedad y temperatura en la cámara son estables, se decide realizar las mínimas actuaciones para que no se modifique el equilibrio higrotérmico. Sucede asi que en la cúpula sólo se propone limpiar el trasdosado de los depósitos actuales para evitar la formación de costras; en la cámara se mejora la ventilación reponiendo las celosías y espaciando los tableros en la plataforma interior; y en la cubierta se aplican tratamientos protectores de las vigas de madera y los refuerzos metálicos.

Se detecta en la sección del edificio que la galeria perimetral es la zona más vulnerable. Por un lado, no está bien ejecutado el encuentro del pavimento con el paramento, lo que ha generado una línea de entrada del agua de infiltración que se ha manifestado desde el interior en una sutil línea que dibuja las pinturas por debajo del remate del muro del tambor con velos y eflorescencias. Ante esto, se propone sustituir el pavimento, mejorar su impermeabilización y resolver dicho encuentro con una zabaleta. Por otro lado, los paramentos están revestidos de yeso y el alero contiene cemento que está aportando sales en la parte superior. Con el apoyo de los estudios histórico y analítico se decide sustituir dichos revestimientos por otros con mortero de cal y sanear el alero.

En esta línea de actuaciones, la limpieza es una actuación inicial en todo proyecto que no sólo influye en la percepción del bien sino que implica la remoción de productos de alteración y posibles agentes de deterioro. En la actuación sobre el edificio se incluyen los trabajos previos, en los que se eliminan los materiales de intervención incompatibles con los materiales originales, tales como morteros de cemento en llagas y revestimiento, morteros bastardos en recercados y morteros de yeso en revestimientos exteriores, siendo sustituidos por morteros de cal; asi sucede en la parte baja del zócalo de la fachada o en el encuentro suelo-pavimento de la galería perimetral de la cubierta. En el caso de los bienes muebles se convierte en una actuación fundamental, no sólo para la recuperación de las policromías que subyacen bajo las diversas capas de polvo, grasas, barnices y cualquier otro tipo de depósitos, sino para liberar la superficie original de numerosos aceleradores y agentes de alteración presentes en las capas retiradas. Dada la amalgama de diferentes técnicas pictóricas, la multitud de intervenciones realizadas, los distintos tipos de protecciones aplicadas y las condiciones de conservación de cada zona concreta, resulta inviable definir un método concreto extrapolable a la generalidad de la superficie pictórica. Por ello, las inspecciones, analíticas y catas planteadas en la intervención para cada elemento y zona determinada, permitirán planificar un método de trabajo claro y sistemático para abordarla de forma coherente.
En otro orden de cosas, la instalación eléctrica no cumple la normativa actual, su trazado discurre a la vista por los paramentos de la nave y, lo que es peor, en muchas ocasiones por los retablos de madera por lo que supone un enorme riesgo para la conservación de los bienes e integridad física de las personas. Se propone su sustitución y sistematización conforme a las nuevas necesidades planteadas. Para evitar de nuevo su paso por lo paramentos, en la planta baja se traslada bajo el pavimento y la planta alta se alimenta desde la cornisa. En el exterior, atraviesa toda la fachada de una manera arbitraria, por lo que se propone su ordenación a ser posible bajo rasante.

\section{Respecto a la adecuación funcional de los espacios}

Se estudian las necesidades actuales que demanda un edificio tan vivido como éste, donde es necesario compatibilizar las nuevas prestaciones de utilización y seguridad hacia los usuarios con los requisitos de conservación contemplados para los bienes. Es por ello que no sólo se interviene en el interior, comprendido como espacio cultual (nave, capillas, tribunas, presbiterio, sacristía y vestíbulo) o espacios servidores (rectoría, distribuidor y despacho), sino que las actuaciones se extienden a la calle para integrar el bien en un itinerario monumental accesible a la escala de la ciudad.

La soleria actual de la nave de la iglesia no se corresponde con la original, ya que ésta debió sustituirse a lo largo de la historia en al menos dos ocasiones. Las losetas actuales son fruto de la donación de nueva solería al inicio del s. XX, aunque muchas de ellas fueron sustituidas tras la reforma de la cripta y construcción del columbario. Fruto de ello no se encuentra en buen estado de conservación y las actuaciones a nivel de instalaciones requieren levantar parte de ella para no afectar a las pinturas murales de los paramentos. No siendo original en dimensiones, color ni trazado, se propone plantear una nueva solería con un tamaño de formato adecuado a la escala monumental del espacio, con una tonalidad que permita la continuidad visual con los paramentos laterales y que proporcione un criterio para la ubicación del mobiliario. En el caso del presbiterio, mucho más alterado, resulta fundamental integrarlo desde el punto de vista espacial y formal con el mismo material aunque con un menor despiece, más acorde con la escala doméstica del espacio. Se mantienen los umbrales de piedra en color rojo como un elemento original que además ofrece pautas de uso, delimitando las zonas con acceso restringido (presbiterio y capillas). Aprovechando esta operación, se retrasa la mesa de altar para disponer de un espacio previo para las celebraciones sacramentales, inexistente en la actualidad.

Es preciso levantar parte de la solería de la sacristía (para ejecutar la instalación de puesta a tierra del pararrayos) y del vestíbulo del acceso secundario (para el trazado del sistema de ventilación forzada de la cripta). El sustituir finalmente todo el pavimento viene determinado por la mala calidad del existente y la contribución a la dignificación de los espacios adyacentes al presbiterio, lugar más sagrado de la iglesia. 
Las tribunas, entendidas como espacios de la nave de la iglesia, no pueden ser ocupadas ya que al tener su acceso desde propiedades con otro régimen horario no puede garantizarse la evacuación hacia otro sector de incendio; es por eso que se adecuan a un nivel básico.

Un aspecto importante del proyecto es que se propone mejorar las condiciones de accesibilidad universal al edificio, registrando un recorrido totalmente accesible desde el exterior hasta las dependencias de la sacristía. Esto implica el tratamiento del pavimento urbano en el acceso principal por medio de una rampa que se comporta como una topografía artificial y la adecuación del pasillo de la nave hacia la sacristía para salvar el desnivel del escalón existente.

Dado que la única manera de acceder de forma directa a la cornisa interior de la nave para el mantenimiento de la instalación de iluminación es desde la terraza sobre el presbiterio, se hace necesario hacer registrable la vidriera oeste, teniendo en cuenta que se monte sobre un bastidor compatible con los materiales originales que en todo caso mejore sus condiciones de conservación. Esta intervención garantiza la permanencia de la vidriera heredada.

Otra cuestión que se ha visto necesario acometer conforme se iba definiendo el proyecto ha sido el mobiliario. El actual es insuficiente a nivel funcional por el aforo disponible y la inexistencia de diversas condiciones de uso; invade el espacio de la nave con una disposición caprichosa que no permite la contemplación del alzado interior con la distancia adecuada, y es heterogéneo en dimensiones y forma. En consecuencia, no sólo se reponen los bancos en la nave, sino que se diseña un mobiliario especifico para el presbiterio acorde con las necesidades litúrgicas.

\section{Respecto a la puesta en valor y musealización del bien} Nuestro propósito es dotar de coherencia al espacio, explicitando la relación entre el edificio y sus bienes muebles, que hemos venido a llamar programa iconográfico.
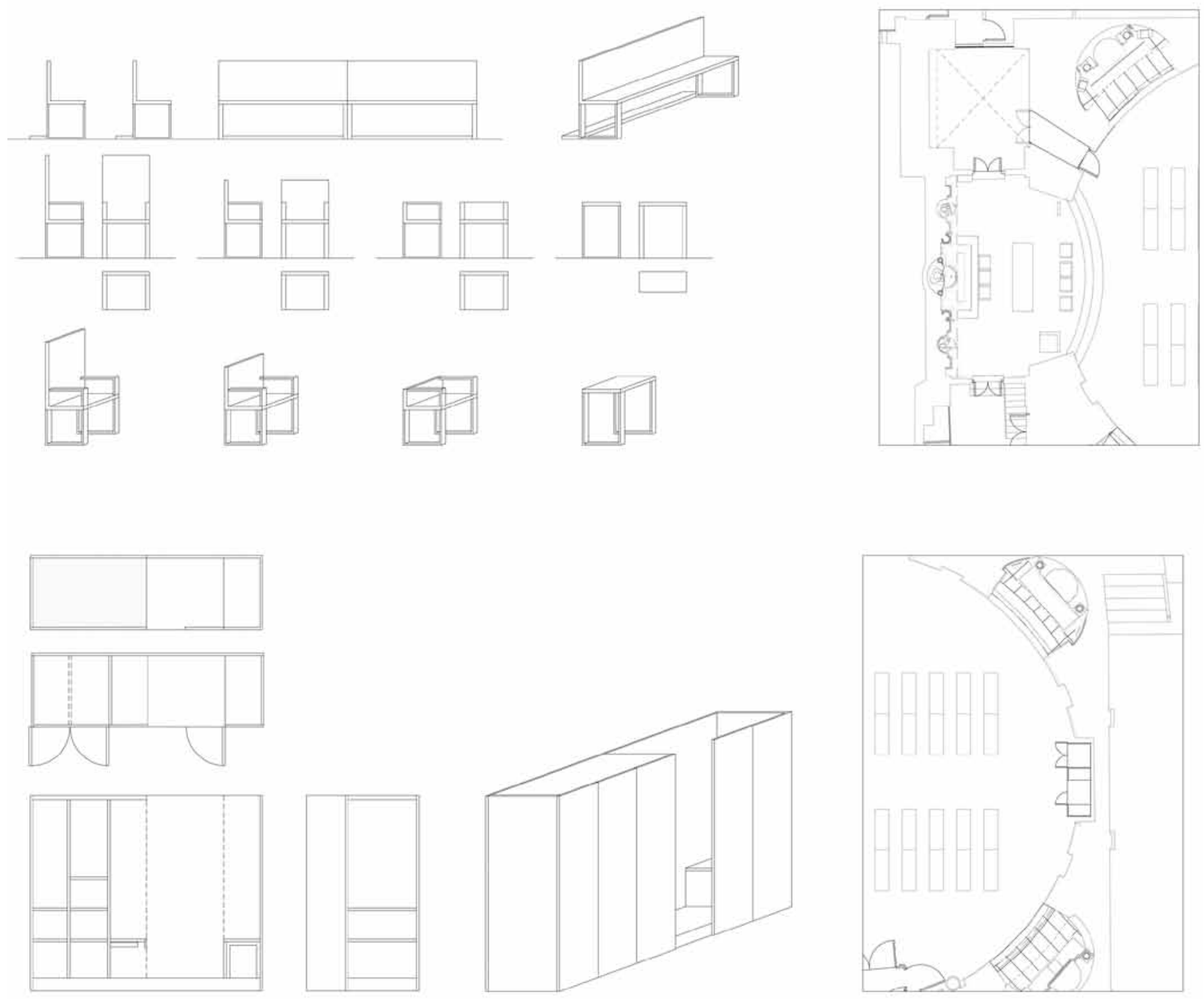

Nuevo mobiliario en presbiterio y nave. Planos: Fondo Gráfico IAPH (Departamento de Proyectos IAPH) 
La decisión de reordenar el programa iconográfico de la iglesia responde a necesidades más profundas ya que el inmueble habia sufrido numerosos cambios de usos de los que se habian derivado cambios y sustituciones en la disposición de los bienes muebles. Sin ánimo de retrotraer este discurso a ninguna de sus etapas históricas, sino considerando ésta como una evolución natural, se aprecia una carencia de criterio y orden -tanto iconográfico como cultual- en las reformas y transformaciones que se han llevado a cabo en el templo desde la segunda mitad del s. XIX, y especialmente en el s. XX. Así, sin nuevas recreaciones, se propone en la medida de lo posible, que las advocaciones originales tanto jesuíticas como del período de Escuela Náutica que aún se encuentran en la iglesia recuperen su disposición histórica. De este modo, se repone un lenguaje reconocible que habla de unas pautas de uso en el edificio en el que las capillas son los espacios cultuales existentes en las diagonales de la nave con una tribuna superpuesta, delimitados inferiormente por un umbral de piedra roja y dos pedestales de pintura mural marmoleada en la misma tonalidad, y superiormente con un encintado de madera policromada.

En consecuencia, se plantea desmontar los altares ubicados en el antiguo hueco de paso al patio del noviciado y frente al presbiterio. En el primero, se propone manifestar su antigua condición de hueco, primero con el paso abierto, luego velado por una cortina o una puerta y finalmente impedido con un cerramiento de fábrica; esto se reinterpreta con un cierre de alabastro que construye un cerramiento fijo y a la vez traslúcido hacia el patio, que actualmente ocupa el colegio. En el segundo, se retiran los elementos existentes para que deje de ser falsamente entendido como una capilla y se incorpora un elemento mueble que hace las veces de confesionario.

En la lectura espacial del edificio, el presbiterio se presenta como el espacio cultual más transformado de la iglesia, en detrimento de las condiciones de uso litúrgicas. Asumiendo la intervención de Martín de Aldehuela como parte de la historia del edificio, a nivel general se decide retirar el pavimento (como ya hemos indicado) y los zócalos recientes. Además, se detectan algunos elementos preexistentes que quieren evidenciarse a modo de huella desde una clave contemporánea. Asi en las tribunas sobre el presbiterio se repara en la continuidad del pavimento existente -por debajo de un frágil cerramiento de color blanco- y la disposición casi simétrica de dos estancias adyacentes con aporte de luz natural desde un balcón frontal al hueco -hacia el patio en el lado norte y hacia la calle en el lado sur-. Abriendo una nueva posibilidad en el edificio sin condicionar ninguna de las actuaciones previstas, se recupera dicho hueco por medio de unas carpinterias de madera plegables que apoyan la idea del presbiterio como un elemento más dinámico y permeable que el actual.

Además, en relación también con la operación de hacer registrable el paso a los espacios servidores de la iglesia, se decide aprovechar las baldosas existentes en el pasillo de la nave a la sacristía, ya que son el pavimento más antiguo localizado en la iglesia. Se tratan a modo de testigo, enmarcadas por el nuevo pavimento.

\section{Nuestro propósito es dotar de coherencia al espacio, explicitando la relación entre el edificio y sus bienes muebles, que hemos venido a llamar programa iconográfico}

La señalética actual no tiene valor cultural y afecta a la conservación de los paramentos, por lo que se propone su sistematización y reubicación en otro elemento. Es más, son varios los elementos muebles sin valor cultural que se proponen retirar definitivamente del inmueble para liberar superficie en planta o rebajar las agresiones en los paramentos: ventiladores, lampadarios eléctricos, reclinatorios, cepillos y otros objetos de pequeño tamaño. Conscientes del valor de uso de muchos de ellos, se toman una serie de medidas complementarias y compensatorias.

Por ejemplo, se propone el diseño de unas nuevas barandillas en latón rojo que resuelven varias carencias detectadas: unifican la imagen de las cuatro capillas que actualmente cuentan con elementos dispares en diseño y altura con una falsa apariencia de antiguo, facilitan la contemplación de las mesas de altar de los retablos de las capillas (se potencia su carácter de elemento horizontal); permiten ser empleadas como pasamanos de un reclinatorio conformado con el umbral original de las capillas (lo que implica la simplificación del mobiliario actual); el pasamanos propuesto permite incorporar un elemento cepillo donde antes se había producido una pérdida de pintura mural en el pedestal $y_{\text {, }}$ por último, dicho soporte incorpora una información cultural en español, inglés y braille que era inexistente.

Para culminar con estas medidas de musealización se proyecta un nuevo sistema de iluminación interior. El actual es insuficiente y obsoleto, por lo que se propone la sustitución de las luminarias en nuevos escenarios de iluminación que apoyen la percepción espacial del interior sin discontinuidades entre el suelo, los paramentos y la cúpula (como sucede con la presencia de la araña y los fluorescentes en la cornisa), que simulen la presencia de la luz natural perdida (en la linterna interior y el cierre al patio) y, fundamentalmente, presenten los colores descubiertos tras el proceso de conservación de las pinturas murales de la manera más próxima a su tonalidad sin afectar a su conservación.

Es por todo esto que decimos que el proyecto se propone desvelar lo visible -lo que estaba ahí pero esperaba ser dotado de coherencia para explicitar sus valores culturales- y descubrir lo oculto -las pinturas murales que quedaban subyacentes o la espacialidad insospechada del presbiterio-. 


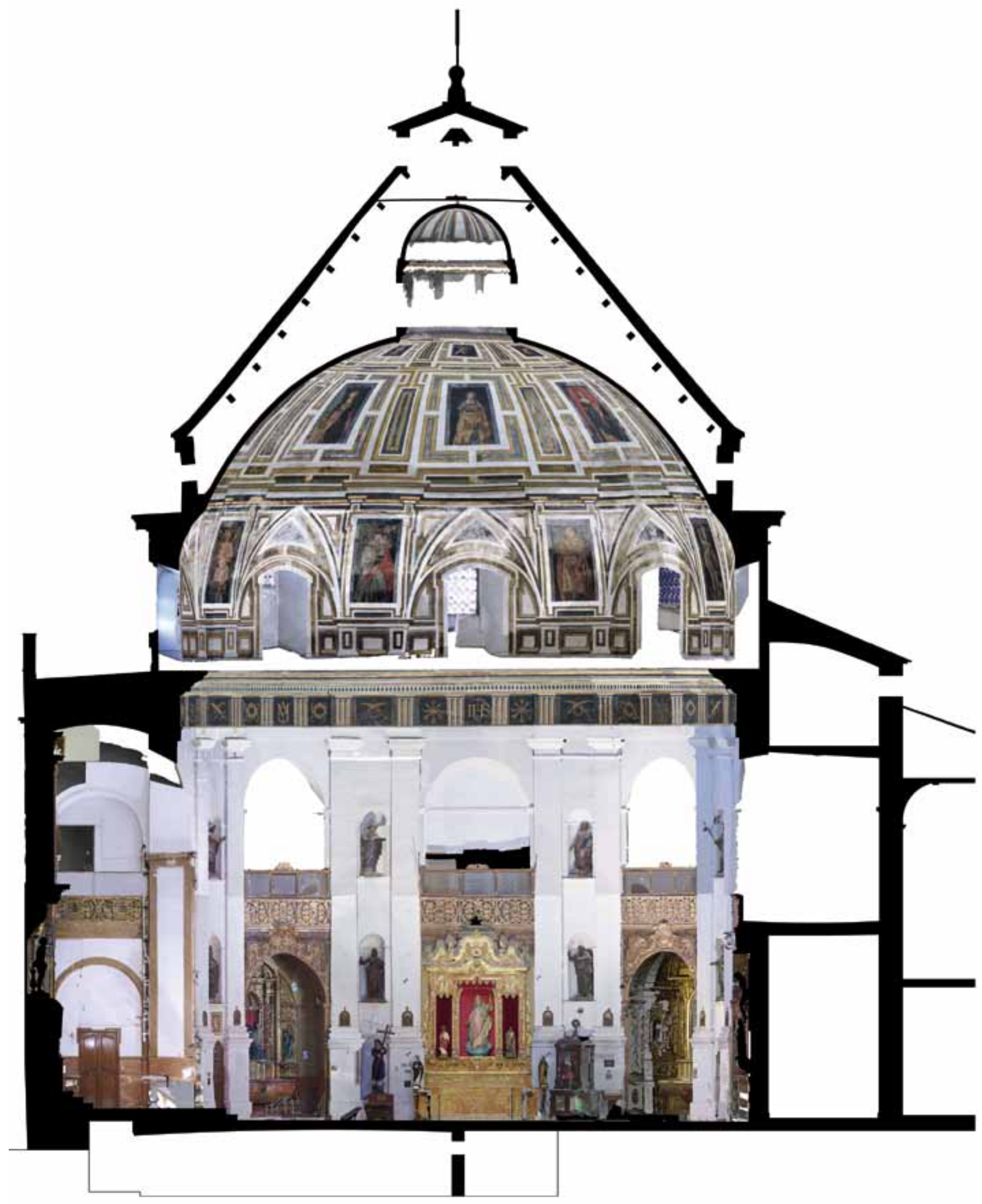

Sección norte. Estado actual y propuesta. Ortofoto: Fondo Gráfico IAPH (TCA geomatica) 


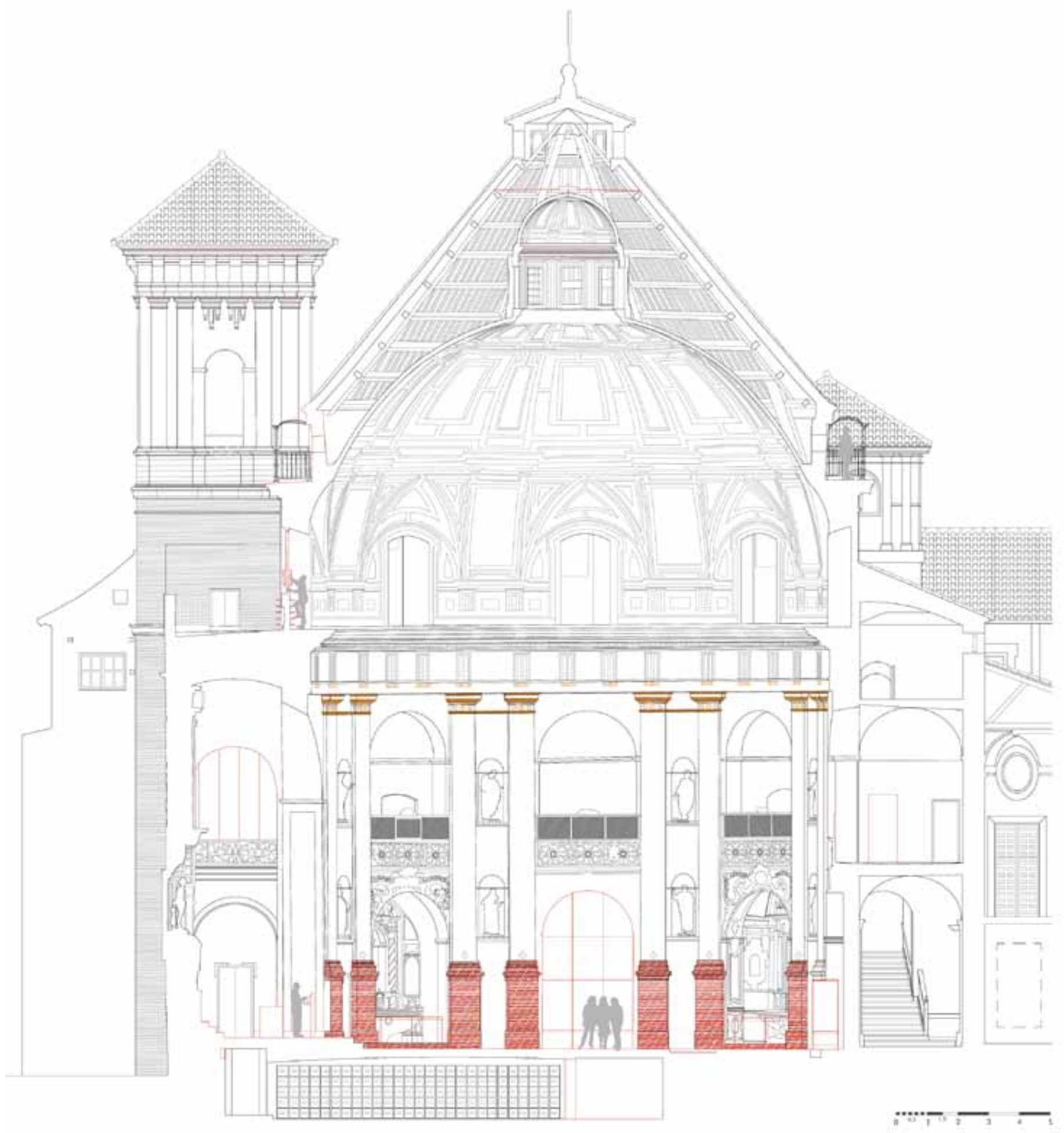

Sección norte. Estado actual y propuesta. Plano: Fondo Gráfico IAPH (Departamento de Proyectos IAPH) 


\section{Para la investigación y el desarrollo}

De acuerdo con la misión del IAPH de ser un referente en materia de investigación, desarrollo e innovación sobre patrimonio cultural y tras su reciente inclusión en el Sistema Andaluz del Conocimiento bajo la denominación de instituto de investigación, este proyecto puede considerarse también como un proyecto de investigación I+D.

Plantearlo como un proyecto de investigación aplicada supone la posibilidad de innovar en las siguientes cuestiones:

- Metodológica. Por primera vez el IAPH acomete la intervención integral en un bien inmueble con un conjunto de bienes muebles asociados. Para ello, como hemos dicho, la estrategia del programa de intervención se plantea desde dos líneas operativas; una para la conservación de los bienes muebles y otra de intervención en el inmueble. Esto implica un esfuerzo de coordinación y supervisión general a favor de una más ágil tramitación administrativa y adecuada distribución de las competencias profesionales. Además es una oportunidad de dotar de contenidos la figura de proyecto de conservación, definida en la Ley 14/2007 del Patrimonio Histórico de Andalucia y pendiente de desarrollo reglamentario. Por último, se enfoca el proyecto de intervención en el inmueble como una experiencia en la que tratar de conciliar la legislación patrimonial con la edificatoria; habida cuenta del debate entre la conservación no sólo de la materialidad, sino de los valores culturales de los bienes y la deseada compatibilidad con las prestaciones de funcionalidad, seguridad y habitabilidad que requieren los usuarios.

- Patrimonial. Implica la conservación de los bienes muebles y también la posibilidad de incrementar este patrimonio a raíz del descubrimiento de nuevas pinturas murales mediante la realización de un programa de catas.

- Tecnológica. Empleo de los últimos sistemas y técnicas de representación para la definición gráfica del proyecto y en apoyo de la difusión, con escáner láser, modelos tridimensionales, ortofotografías e imágenes panorámicas $360^{\circ}$ de alta resolución.

- Investigadora. La investigación histórica trasciende la importancia del propio edificio y lo vincula a una tradición arquitectónica que parte de una orden religiosa -la Compañía de Jesús- con un modelo arquitectónico e iconográfico muy reglado, del que la antigua iglesia de San Sebastián (actual del Santo Cristo de la Salud) supone una de las escasas licencias o alternancias a nivel mundial. - Científica. Posibilidad de empleo de técnicas de análisis no destructivo.

- Gestión. Se adopta una fórmula de gestión directa como garantía de calidad del proceso de redacción-licitación-ejecución de las intervenciones, lo que posiciona al IAPH entre las demás instituciones dedicadas al patrimonio cultural.

Con todo esto será posible la transferencia de aportaciones operativas (que el material generado pueda servir de base para otros estudios e intervenciones sobre los bienes) y aportaciones metodológicas (que genere buenas prácticas extrapolables a otras experiencias).

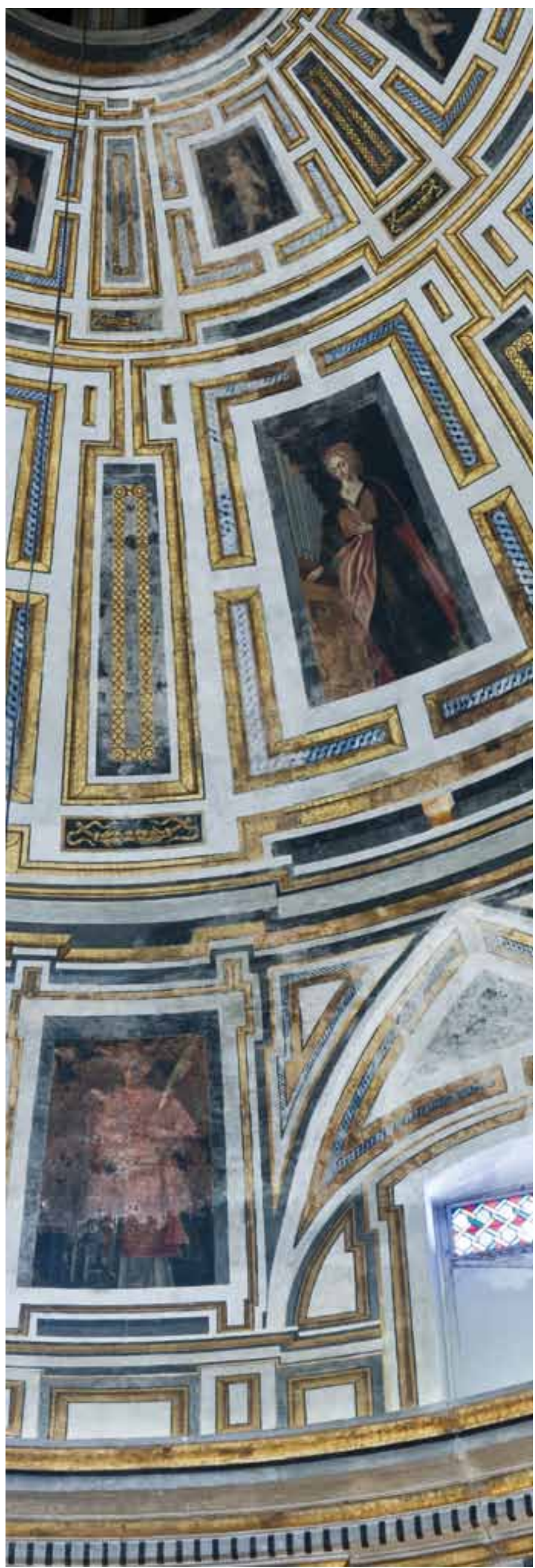

Detalle de pinturas murales en la cúpula.

Foto: Fondo Gráfico IAPH Uosé Manuel Santos Madrid) 


\section{DIRECCIÓN DEL PROYECTO}

Román Fernández-Baca Casares, director del IAPH

\section{COORDINACIÓN GENERAL}

Lorenzo Pérez del Campo, jefe del Centro de Intervención en el Patrimonio Histórico (Cl-IAPH)

\section{COORDINACIÓN ESTUDIOS ANALÍTICOS}

Rosario Villegas Sánchez, responsable de la coordinación científica del Programa de Investigación de los Laboratorios y Análisis del IAPH

\section{COORDINACIÓN TÉCNICA CONSERVACIÓN}

Araceli Montero Moreno, jefa del Área de Tratamiento de Bienes Muebles (Cl-IAPH)

Marta García de Casasola Gómez, jefa del Dpto. de Proyectos (Cl-IAPH)

\section{COORDINACIÓN DE GRUPOS}

Proyecto de conservación de bienes muebles:

M. ${ }^{a}$ del Mar González González, jefa del Dpto. de Talleres de Bienes Muebles (Cl-IAPH)

Proyecto de intervención en inmueble:

Aurora Villalobos Gómez, arquitecta, Dpto. de Proyectos (CI-IAPH)

\section{EQUIPO TÉCNICO}

\section{Proyecto de Conservación de BIENES MUEbles}

Redacción y dirección técnica:

M. ${ }^{a}$ del Mar González González, restauradora, jefa del Dpto. de Talleres de Bienes Muebles (Cl-IAPH)

\section{Redacción:}

Fernando Guerra Librero, arquitecto-restaurador

Estudios de técnicas de examen por imagen:

Eugenio Fernández Ruiz, jefe de Proyectos de Técnicas de Examen por Imagen (Cl-IAPH); José Manuel Santos Madrid, fotógrafo, Laboratorio de Técnicas de Examen por Imagen (Cl-IAPH); Francisco José Sánchez Díaz, jefe del Laboratorio de Cartografía e Imagen Digital (CDE-IAPH); Juan Carlos Cazalla Montijano, fotógrafo, Laboratorio de Cartografía e Imagen Digital (CDE-IAPH)

Estudios medioambientales:

Raniero Baglioni, Unidad de Conservación Preventiva (CI-IAPH)

\section{Proyecto de INTERVención en el INMUEBLE}

Proyecto básico y de ejecución de intervención en el inmueble

Redacción y dirección de las obras:

Román Fernández-Baca Casares, arquitecto, director del IAPH; Marta

García de Casasola Gómez, arquitecta, jefa del Dpto. de Proyectos (ClIAPH); Aurora Villalobos Gómez, arquitecta, Dpto. de Proyectos (CI-IAPH)

Dirección técnica trabajos de restauración:

Ana Bouzas Abad, restauradora, Taller de Patrimonio Arqueológico (ClIAPH)
Asesoría instalaciones:

Ángel Luis León Rodríguez, arquitecto, ESTIN SC arquitectos

Colaborador en redacción:

Antonio A. Carrasco Delgado, arquitecto

Levantamiento planimétrico

Responsable levantamiento 2D y ortofotografía:

José Manuel López Sánchez, TCA geomática

Responsable modelado 3D e infografía:

José Luque Bellido, arquitecto, Plan9

Proyecto de andamios, instalaciones y medios auxiliares

Redacción:

Manuel Cárdenas Mansfeld, Mariano Asuero Orta, Fernando Serrano Gaviño, a de c integral de proyectos

Estudio de seguridad y salud

Redacción:

Manuel Cárdenas Mansfeld, Mariano Asuero Orta, Fernando Serrano Gaviño, a de c integral de proyectos

\section{ESTUDIO HISTÓRICO}

Coordinador de estudio histórico:

José Luis Gómez Villa, historiador, Área de Investigación (Cl-IAPH)

Análisis fuentes documentales:

Igor Vera Vallejo, historiador

Gestión documental en fase previa:

Sara Martín Asensio, documentalista

\section{ESTUDIOS ANALÍTICOS}

Estudio geológico:

Jesús Espinosa Gaitán, geólogo, Laboratorio de Geología (CIA-IAPH)

Estudio biológico:

Marta Sameño Puerto, jefa de Proyecto del Laboratorio de Biología (CIAIAPH); Victor Menguiano Chaparro, biólogo, Laboratorio de Biología (CIA-IAPH)

Estudio químico:

Lourdes Martín García, jefa de Proyecto del Laboratorio de Química (CIA-IAPH); Auxiliadora Gómez Morón, Laboratorio de Química, (CIAIAPH); Abel Bocalandro Rodríguez, químico; Elena Revuelta Camacho, ingeniera industrial

\section{COMUnicación}

Plan de comunicación:

Beatriz Sanjuán Ballano, periodista, jefa del Dpto. de Comunicación (DEC-IAPH) 